\title{
Religion and Democracy: Perspective of Abdurrahman Wahid
}

\author{
Elly Warnisyah Harahap ${ }^{1}$, Syahrin Harahap ${ }^{2}$, Amroeni Drajat ${ }^{2}$ \\ ${ }^{I}$ Ph.D Student in State Islamic University of North Sumatera, Medan, Indonesia \\ ${ }^{2}$ Lecturer in State Islamic University of North Sumatera, Medan, Indonesia \\ ellyharahap7@gmail.com
}

\section{Abstract}

This paper describes the thoughts of Abdurrahman Wahid (Gus Dur) about religion and democracy. Abducting Abdurrahman's thoughts about religion and democracy today is not only relevant, but important, especially in the midst of various radicalism issues that are currently being discussed today. The issue of radicalism which is generally directed at Muslims is suspected because of the desire of a group of Muslims to make Islam appear in its formal form in this country, in other words they want to make Indonesia an Islamic state. This desire which was opposed by Abdurrahman by considering the plurality of the nation, especially according to Abdurrahman, there is no standard provision of the state in Islam. By using library data, it is concluded that specifically in seeing the relationship between Islam and democracy there are three kinds of responses, namely integrative, facultative, and confrontational. In addition, Abdurrahman firmly said that Islam does not need to be present in a formal form in this country, just enough substance that is when Islamic values are realized in democracy, because the teachings of democracy do exist in Islam.
Keywords

Religion; democracy, Islam Abdurrahman

Wahid

\section{Introduction}

Democracy is an interesting topic to be discussed, both by academics and politicians, even by ordinary people. Whatever process happens in the main country, it is always associated with democracy. Yes, since it was first applied in its home country, Greece, this system is considered more likely to realize a better state of life compared to the previous systems that already exist. This belief is not without reason. "A sovereign people", that is what is considered to make the country can realize true prosperity, guaranteed human rights and freedom of speech.

Democracy is basically implemented in a country with the aim of appreciating the interests of the people, not the interests of the authorities. Indeed, a leader in a democratic country is only the bearer of the mandate and which accelerates while ensuring the fulfillment of the rights of citizens, ensuring justice, as well as equitable distribution of development results. When people are sovereign, whatever is deemed incompatible with the interests and aspirations of the people, then it must be abolished. That is ideally.

So many countries have made democracy their system of government, and so many models of democracy in the world. Even though democracy is the same, it turns out that the models of democracy that are applied in each of the countries are not the same. Basically democratization suggests the changing process to strengthen the sovereign of people as according to democratic value. Democratization also can be defined as a process to a more democratic action, signed by the ending of authoritarian realm, constructing a democratic realm and the occurrence democratic realm's consolidation. There are those who implement liberal democracy, there are also socialist democracies. Indonesia did not even implement one 
of the two models. Indonesia, as said by Sukarno, implemented Pancasila democracy, meaning democracy based on Pancasila, the basis of the Indonesian state.

Uniquely, the democratic model adopted in Indonesia, was quipped by Abdurrahman by saying, that Indonesia is a no-nonsense, not a capitalist, but not a socialist country. Yes, that is unique to Indonesia, but that is the uniqueness of Indonesia's identity in the midst of the diversity of countries in the world.

At first glance, this expression shows both distrust and ridicule of the democratic model that Indonesia practices, but on the other hand it shows Gus Dur's honesty in assessing his own country as well as the uniqueness of his way of thinking. Abdurrahman was indeed unique, often making strange statements, and Gus Dur did not care about people's judgment on him. Gus Dur will continue to run with his own thoughts, with his own beliefs. Gus Dur's attitude and way of thinking is one of the things that makes Gus Dur interesting to talk about. His thoughts which for some people are considered strange and even strange, on the other hand for those who really understand him are considered to think beyond his time, as one of the kiai from Pandeglang reiterated by Yenni Wahid in an interview on television on the Kick show Andy.

\section{Review of Literature}

\section{Gus Dur the True Democrat}

Abdurrahman Wahid, familiarly called Gus Dur, was born in Denanyar on 4 August 1940 on Friday. This figure who had been the fourth President of the Republic of Indonesia was known as a figure with a myriad of abilities, experiences and designations. He was a scholar, politician, culturalist, father of pluralism and humanist. Born of the offspring of the cleric, the famous kiai. His father Wahid Hasyim was not only a cleric but had been Minister of Religion during the Soekarno era. His father's grandfather was a well-known and influential kiai, kiai Hasyim Asy'ari, owner and founder of the Tebuireng pesantren, Jombang, a pesantren which until now has remained strong and has produced prominent scholars in the country. Kiai Haji Hasyim Asy'ari is the founder of Nahdlatul Ulama, a wellknown Islamic religious organization in the country. His maternal grandfather, kiai Bisri Syansuri, was also a prominent cleric, founder of the pesantren Denanyar. Kiai Bisri Syansuri was also active in NU and raised this most-member organization.

Gus Dur's life and education background is quite rich. Since childhood, Abdurrahman was familiar with the life of the pesantren, and studied religion from his two grandfathers, but he also had a good general education. It shows clearly how Abdurrahman had a good religious education and general education since he was a child. No wonder then that Gus Dur's knowledge was very rich which was reflected in his writings. Abdurrahman was able to write and analyze straightforwardly the problems from the political, social, economic, moral, even sports issues, especially soccer, the sport that he was most interested in. That is why, according to Ahmad Wahib's diary, it is said that "Gus Dur is not a sociologist, not a politician, not a politician, not an artist, not a culturalist, not a religious person, not a feminist, and also not a thinker, but Gus Dur is everything ".

Gus Dur's track record is very broad, but as revealed in the Editor's Introduction to the book Beyond The Symbols, Gus Dur's writings since the 1970s feel a deep reflective nuance for several branches of science, but he does not appear to be an expert in one field of science. Even so, he studied so many objects of study interestingly, sharply with clever ideas, but still short and incomplete. Gus Dur as the initiator and thinker is indeed very advanced and 
creative to throw new things, but everything can be said to be related to his desire to realize the true democracy in his country.

As a thinker and activist, Abdurrahman was very intense in talking about democracy, and even fought for it. During the Soeharto government, Abdurrahman founded the Democracy Forum, a New Order policy suppressor organization which was known to be active in criticizing the government. It can be said that Abdurrahman spent a quarter of a century more time as a democracy fighter. His greatest struggle to realize democracy is when he successfully deals with the Aceh and Papua conflicts. Through a personal and psychological dialogue approach, Abdurrahman successfully re-embraced GAM activists (Free Aceh Movement), and OPM (Free Papua Organization), so that both (Aceh and Papua) did not become free.

Because of his democratic attitude as well, Abdurrahman easily left the presidential palace when the MPR impeached him, as though without a burden, even Abdurrahman detained and forbade his followers to take action against the MPR's decision. Gus Dur revealed in the preface to the book L.Misbah Hidayat, Administrative Reform; A Comparative Study of the Three Presidents that although Abdurrahman received written support from 3000,000 to retain his presidency, Abdurrahman chose to be removed from office to avoid civil war.

\section{Discussion}

\subsection{Gus Dur's Democracy}

Gus Dur was undoubtedly a democracy fighter. The desired form of democracy is fought through writing and real activities. Likewise, if divided periodically, in the 1970s to 1980s, the periods during which Gus Dur was very productive and creative in writing, could be called Gus Dur's "scientific period". At this time Abdurrahman was devoted to writing using social science methodologies, especially anthropology, with a focus on writing on cultural, socio-political, and religious issues directly related to the life of pesantren. This could be understood because those periods were the periods where Gus Dur was directly involved in the life of the pesantren, because Gus Dur was indeed a teacher there, moreover Gus Dur was the grandson of the founder of the Tebuireng pesantren, Jombang.

The next period, namely the 1980s to early 1990s, was the period when Gus Dur gave rise to many of his ideas about democracy, religious pluralism, humantarianism, freedom of opinion, the indigenization of Islam, and others. These were the periods where Abdurrahman was not only a writer of political issues, but also a political praxis. The ideas he introduced in the 1970-1980 era were realized at this time.

The latter period was the period in which Gus Dur appeared to be more of a politician, involved in tumultuous domestic political events in the late 1990s, and the productivity of his writing declined, but there was no doubt that his thoughts and desires remained the same, making sharp criticisms to whatever he thinks is inappropriate, and to do whatever he thinks must be done in order to realize his dream of a democratic state in which all people are filled with their human rights regardless of whether they are majority or minority. During this period Gus Dur was elected by the MPR as President, but his statements and maneuvers were even more eccentric and controversial.

Gus Dur did write many things, and played many roles too, but all of them were actually connected with Gus Dur's ideals to realize the ideal democracy he wanted, namely democracy without violence. In this context, Abdurrahman preferred to identify through his 
writings in various print media where between him and his audience there was an idealistic identification, namely sharing ideas, attitudes, feelings, and values. This is what Burke refers to as substance.

For Gus Dur, democracy is not only a system that is able to guarantee freedom of advocacy, but at the same time has an ethical nuance that is capable of giving birth to justice without violence. That happens because democracy opens dialogue space in a balanced and equal way between all parties, although the results are not always in the form of an agreement. Democracy does not have to produce important agreements or consensus, but the most important thing is the emergence of understanding and respect for universal human values.

Democracy is a process that is always in a state of being, it means that democracy is dynamic. There are many things that influence it to continue to develop towards its best form, so it needs the awareness of all elements of the nation to make it happen through dialogue and openness.

Democracy is a necessity that must be met in civil society, because democracy is very possible to form a pattern of interaction and political relations that are balanced and not exploitative. More than that, democracy also creates appreciation for the condition of the plural Indonesian people. Abdurrahman also believed that "democracy will continue to be realized in a dominative-hegemonic situation, with a note that if space is still open, human beings will be free and sovereign."

As a person whose pesantren base was so strong, Gus Dur linked democracy to the teachings of Islam. For Gus Dur democracy is one of the basic values of three values which describe the Islamic weltanschauung, namely 'is, musawah, and shura. Musawah means equality before the law, showing the rule of law that leads to justice ('is). At this point, the democracy that Gus Dur wanted was referring to social democracy. Democracy is not only form (form), but also material (material), which contains wisdom / wisdom (shura-pen.) Which refers to Islamic social ethics. With this, it is clear that Gus Dur's desire to fulfill political civil rights and socio-economic rights at the same time.

\subsection{Religion and Democracy}

Komaruddin Hidayat stated that there were three models of the relationship between religion and democracy, namely: negative, neutral and positive. First, the relationship between religion and democracy is negative when religion is in a state of counter-democracy. History of religion, historically-sociological shows that the role of religion is often used by political authorities and leaders of religious organizations as a tool to support the political interests of groups. The existence of religion which always gives birth to a social grouping, will eventually give birth to sectarianism understanding and movement. "Religion theologically does not have the cooetensi of speaking and resolving democratic problems because religion is deductive, metaphysical, and always refers to God who is present empirically, while democracy is an empirical, concrete, and dynamic problem."

The negative relationship of religion with democracy can be traced since the renaissance period where the dominance of the church was finally defeated by science, and democracy is one part of it. The birth of democracy at that time was a symbol of resistance (counter) to the dictatorship of the authorities who took refuge behind the institution of the church.

Second, the neutral relationship between religion and democracy. Religious and political affairs here operate independently, known as political secularization. This 
secularization can only take place at the formal level of religion, social processes, or the level of metaphysical awareness or it can also take place all at once. This is because people's trust in religious institutions has diminished to resolve economic and political problems, but that does not mean those who support anti-religious political secularization. There is only a separation of roles and positions, religion is considered to only play a level of personal awareness when dealing with God, and when facing situations of existence and the search for meaning in life. Democracy acts as etiquette and social ethics whose arrangements are left to human rationality.

Third, the relationship between religion and democracy is positive, which is termed the theo-democracy. In this connection, religion both theologically and sociologically supports the process of political, economic and cultural democratization. Democracy is considered a word that contains dignified values, so that religion then identifies itself with democracy. Shaykh Yassin - to take an example from Muslims - even firmly said that Islam believes in democracy.

Specifically, in seeing Islam's relationship with the state, Gus Dur divided it into three types of responses, namely integrative responses, facultative responses, and confrontational responses. In the integrative response, Islam completely eliminates its formal position, and religious teachings have nothing to do with state affairs. The relationship of Muslim life with the state is only determined by the pattern of social life that they follow that is influenced by their respective educational and cultural backgrounds.

Facultative response is shown when the power of the Muslims is quite large in parliament, and this causes their desire to make legislation in accordance with Islamic teachings. If the power is not big enough, then they will decide by accepting the rules even though they are different from Islamic teachings. The confrontational attitude firmly refused from the beginning what was considered "un-Islamic".

Specifically, Gus Dur also analyzed the relationship between religion (Islam) and democracy. His thinking about the relationship between the two by paying attention and considering the reality of a pluralistic Indonesian society.

Gus Dur believed that democratic values existed in his religion, namely Islam. Because democratic values already exist in Islam, there is no need to realize Islam in a formal form in a democratic country, Indonesia. Yes, what Gus Dur really wants is the substance of religious teachings embodied in democracy, so that this country does not need to become an "Islamic state", as demanded by some Islamists. Sufficient Islamic values are shown, because indeed the teachings of democracy exist in Islam.

More explicitly Gus Dur said that in the context of religion in a democratic country the formalization of religious teachings was not necessary. The most important thing is how to make Islam fight for democracy in the context of developing citizens' understanding to develop democracy. The state should serve all parties. Therefore Islam does not need to be formalized in the life of the state. It is enough if the citizens fight for the role and contribution of Islam informally in developing democracy.

This view is based on his belief that the concept of the state does not exist in Islam, so the implementation of Islamic statehood is very contextual. Religion (including Islam-pen.) According to Gus Dur always starts from the normative view taught by his holy book, because there is only one type of truth according to religion, namely the truth of religion itself. Because religion is based on holy books that are eternal, religious law is also eternal, because there is no gap to change religious law, because changing religious law means 
limiting the immortality of the scriptures, and that means disturbing the truth brought by religion itself.

Democracy is just the opposite, opening as wide open opportunities for value changes by society. This means that it will threaten the eternal values contained in religion. Democracy also requires equality of rank and position of citizens in the law regardless of ethnic origin, religion, gender, and mother tongue. Each religion tends to look for differences first, at least differences in religion and belief.

The above facts cause clashes between religion and democracy to occur. Changes in values by people who are given the opportunity by democracy have the potential to threaten eternal values in religion, can be exemplified by the conversion of religion (converting). For Islam, someone who is apostate (out of Islam) is threatened with the death penalty, while in a democratic country freedom of religion is guaranteed including changing or converting from one religion to another. The state has no right to punish if its citizens do this.

Gus Dur believes that Islam is a religion of democracy, with the excuse: First, Islam is a religion of law, which treats everyone equally regardless of one's position and position. Secondly, Islam has a principle of consultation, which is explained in the Qur'an "Amruhum syurâ bainahum". (their matters are discussed among themselves). Third, Islam always holds the view to improve life. The world is essentially a preparation for a better and eternal life hereafter, therefore humans must continue to improve their standard of living.

Gus Dus's thought about the relationship between religion and democracy was already introduced by Gus Dur in the early days of Gus Dur actively writing, in the 1970s. Throughout the 1970s Abdurrahman's view was clear about the relationship between religion and democracy. If identified, indeed Gus Dur's writings on democracy can be divided into three parts, namely: a. The role of religion in the process of democracy and development; $b$. Democratic values in pesantren, and c. Democracy in a pluralist society.

a. The Role of Religion in the Process of Democracy and Development.

Basically every religion has a transformative character, which is trying to instill new values and replace old values that are considered contrary to religious teachings, Gus Dur said. Religion must reformulate its view of human dignity and equality before the law, as well as collaborating with other religions to achieve universal values, which are expressed by concrete services to people without vision, for example through poverty alleviation, upholding the rule of law, and freedom express an opinion.

For NU, the organization where Gus Dur was chairman of Tanfidziyah for around 10 years, this was adopted with the term: al-muhafadzatu 'alal qodimis sholih ma'al-akhdzi bil jadidil ashlah (preserving a good old legacy and taking new things better).

Efforts to revisit Islamic teachings can be done by: First, changing the interpretation of existing teachings; Second, bring up new teachings that better represent religious aspirations in facing the challenges of the situation. If these two things are done, then the attitude of clashing religion with democracy carried out by a group of people can be resisted in an elegant way. It is this attitude that makes religious groups considered opponents to the ongoing process of democracy.

In addition to the need to reinterpret religious teachings, Gus Dur also criticized religious leaders. Abdurrahman assessed that religious leaders were unable to understand the reality in society where the impoverishment process was taking place, which was evidenced by the gap between the rich and the poor which were increasingly widening. 
Gus Dur said religious leaders and followers had doubts about the direct relationship between religion and development. Religious leaders impose development programs on the community without any logical explanation that can be understood so that people with their own conscience want to follow it. For example, the KB (Family Planning) program which is expected to be carried out by the community as one of the efforts for the welfare of the nation and delivered by linking it with religious teachings, but on the other hand, the actual implementation of KB parts that deviate from religious teachings continues.

To overcome this problem, Gus Dur put forward the following solutions: first, inviting the community to formulate their own basic needs. Secondly, making the whole community aware of the latent dangers inherent in the process of disparity between the rich and the poor. Third, invite the community as a whole to stop the process of mastering the main economic resources in the form of capital, land, and technical skills in the hands of a small number of community members who are considered to be the cause of the gap.

\section{b. Democratic Values in Islamic Boarding Schools.}

In formulating the democracy he wanted, Gus Dur analogized a lot with the life of the pesantren. Gus Dur really understood the life of the pesantren because of his background as the grandson of the founder of the pesantren and he himself spent most of his childhood and adolescence at the pesantren. Abdurrahman saw that the spirit of democracy was part of the pesantren. That is why his ideas about democracy often use terms in the pesantren tradition.

Gus Dur saw the democratic attitude of the kiai in facing the changes and developments of the times. In his writings entitled "Mahdiism and Social Protest" Abdurrahman explained about freedom of opinion and overcoming rebellion as a logical consequence of diversity. Gus Dur in his writings also showed hope and belief that a messianic religious movement which generally had a strong character if properly socialized, would become a human who had a depth of nature as a pioneer of development.

Another characteristic that is seen in democracy in pesantren life is tolerance. Tolerance is more rewarding as an effort to resist the expansion of the opponent's influence. This was demonstrated by one of the NU kiai, the Chasbullah kiai who was used as a strategy of his struggle in resolving disagreements. In the life of pesantren, especially Denanyar boarding schools the differences and fanaticism were high at that time, the appreciation of differences was so high. That is the pesantren tradition. So the spirit of democracy in advance had been traditionalized in the life of Islamic boarding school.

Islamic boarding school must be able to be an agent of change (cultural broker) for the surrounding community through a value system transmitted from generation to generation to students and the community. In addition, pesantren must also be able to absorb cultural changes that are and will develop in society, without losing the values that have been owned so far.

\section{c. Democracy in Pluralist Society.}

The democracy that Islamic boarding school wanted was a democracy that played a role in the reality of a plural society. As a statesman, Gus Dur with his vast experience really understood the diversity of the Indonesian people. Indonesia is not only diverse in ethnicity, culture, customs, but also religion. This awareness made Gus Dur attach great importance to the unity of all components of the nation in this plural society. His idea of pluralism was born because of this awareness. Democracy and pluralism are very closely related, especially for Indonesia, which is known to be very plural and multicultural. 
Pluralism can be interpreted as understanding that tolerates the diversity of thought, culture, civilization and religion or beliefs. In Islamic doctrine, pluralism means the emphasis of Islamic inclusivism which is seen at two levels: the level of doctrine, and the historical level or historical experience. ${ }^{1}$

At the level of doctrine, the emphasis on Islamic inclusivism can be seen for example in the Koran surah al-Hujurut verse 13:

"O people, verily We created you from a man and a woman and made you nationals and tribes so that you knew one another. Surely the most noble of you in the sight of Allah is the most pious among you. Verily Allah is All-Knowing, All-Knowing. "(Surah al-Hujurât $\{49\}$ : 13).

The plural reality seen by Abdurrahman in the life of the people in Indonesia, coupled with the Qur'anic statement itself made Abdurrahman a pluralism fighter. The very pluralistic experience of the Indonesian nation was well understood by all elements of this nation from the beginning even before the country was formed. That is why NU (Nahdlatul Ulama) figures such as K.H. Hasyim Asya'ri (Gus Dur's grandfather), and K.H. Wahab Chasbullah has been thinking about how to place Islam so that it can function in a pluralistic Indonesian society and at the same time be able to coexist peacefully with other religious adherents. Although Muslims are the majority population, NU figures do not want to make this country in the form of an Islamic state. Indonesia (formerly still called the Dutch East Indies) did not need Islam as a state ideology, but Muslims were still obliged to defend their country. ${ }^{2}$ That's what Gus Dur followed and continued throughout his life.

The upholding of community pluralism according to Gus Dur lies not only in a pattern of peaceful coexistence, but more than that there is an awareness to know each other and engage in sincere dialogue between groups, so that there is an attitude of giving and taking (take and give) between groups, and this is one of the substance of democracy. ${ }^{3}$

Democracy in a pluralistic society must provide a space for sincere dialogue between different groups while developing an attitude of understanding differences, so that peace is created. Gus Dur said: "Indonesia's pluralism is the most powerful compared to other countries. Therefore, the difference does not need to be politicized ". His persistence in defending pluralism led Abdurrahman to receive the Medals of Valor award from The Simon Wieenthal Center in the United States, because he was determined to fight for moderation in Islam and establish an open dialogue with other religions, which would certainly have an impact on creating world peace.

\section{Conclusion}

Gus Dur was undoubtedly a person who consistently fought for democracy throughout his life. His thoughts on democracy are inspired by his religious teachings, namely Islam which he empirically found in pesantren. He believes that democracy is one of the basic values of Islamic teachings. Likewise in state life, Abdurrahman did not want Islam to appear in its formal form, but it was quite substantial. This is considering that Indonesia as a country in which plurality in terms of ethnicity, culture, and even religion is a reality that cannot be denied. Plurality is actually a wealth that must be maintained.

\footnotetext{
${ }^{1}$ Katimin, Politik Masyarakat Pluralis Menuju Tataran Masyarakat Berkeadilan dan Berperadaban, (Bandung: Citapustaka Media Perintis, 2010), p. 201

${ }^{2}$ Irwan Suhanda (Ed.), Gus Dur Santri Par Excellence, (Jakarta: KOMPAS, 2010), p. 199.

${ }^{3}$ Ahmad Salehuddin, Abdurrahman Wahid Keislaman..., p. 134.
} 


\section{References}

Abdurrahman Wahid. (1999). Islam, Negara, dan Demokrasi Himpunan Percikan Perenungan Gus Dur, Harian Media Indonesia, dalam Imam Anshori Saleh (Penyusun), Jakarta: Erlangga.

. (2011). “Administrasi Negara dan Dunia Politik", Kata Pengantar untuk buku L. Misbah Hidayat, Reformasi Administrasi: Kajian Komparatif Tiga Presiden, Penyusun. Tri Agus S. Siswowiharjo, Sekedar Mendahului: Bunga Rampai kata Pengantar K.H. Abdurrahman Wahid, Bandung: NUANSA.

(1999) (Ed.), Mengurai Hubungan Agama dan Negara, Penyusun:

Kacung Marijan dan Ma'mun Murod al-Brebesy, Jakarta: Grasindo.

Ahmad Salehuddin. (2019). Abdurrahman Wahid, Keislaman, Kemanusiaan dan Kebangsaan, Yogyakarta: Basabasi.

Ahmad Suaedy. (2018). Gus Dur, Islam Nusantara \& Kewarganegaraan Bineka Penyelesaian Konflik Aceh \& Papua 1999-2001, Jakarta: Gramedia Pustaka Utama

Andreas Harsono et.al. (2010). Hari-hari Terakhir Gus Dur di Istana Rakyat, Jakarta: Pensil324 ,

Greg Barton, (2016). Biografi Gus Dur The Authorized Biography of Abdurrahman Wahid, Terj Lie Hua, Yogyakarta: Saufa.

Iryadi, I., et al. (2019). Muslim and Democracy: A Reflection from 2012 Aceh's Gubernatorial Election. Budapest International Research and Critics Institute (BIRCIJournal), 545-555.

Irwan Suhanda (Ed.). (2010). Gus Dur Santri Par Excellence, Jakarta: KOMPAS.

Katimin, (2010). Politik Masyarakat Pluralis Menuju Tataran Masyarakat Berkeadilan dan Berperadaban, Bandung: Citapustaka Media Perintis.

Komaruddin Hidayat. (2019). "Tiga Model Hubungan Agama dan Demokrasi", yang dikutip Ahmad Salehuddin, Keislaman, Kemanusiaan, dan Kebangsaan, Yogyakarta: Basabasi,

M. Imam Aziz, (2002). Kumpulan Kolom dan Artikel Abdurrahman Wahid, Yogyakarta: LkiS.

Munawar Ahmad. (2012). Ijtihad Politik Gus Dur Analisis Wacana Kritis, Yogyakarta: Lkis,

Nur Kholisoh, (2010). Demokrasi Aja Kok Repot Retorika Politik Gus Dur dalam Demokrasi di Indonesia, Yogyakarta: Pohon Cahaya,

Payaman D. Simanjuntak, et al. (2000). Gus Dur Sang Rekonsiliator, Jakarta: Himpunan Pembina Sumberdaya Manusia Indonesia (HIPSMI).

Syaiful Arif, (2013). Humanisme Gus Dur Pergumulan Islam dan Kekuasaan, Yogyakarta: AR-Ruz Media.

Tim INCRëS, (2000). Beyond The Syimbols Jejak Antropolgis Pemikiran dan Gerakan Gus Dur, Bandung: Remaja Rosdakarya. 